\title{
Study on Chinese Cruise Tourism Supply and Demand Equilibrium based on GM $(1,1)$
}

\author{
Xia LI \\ Shanghai University of Engineering Science, Shanghai, China; lixia-2002qufu@163.com \\ Ming SHAO \\ Shanghai University of Engineering Science, Shanghai, China; 1078383509@qq.com
}

\begin{abstract}
Chinese cruise tourism has embarked on a track of rapid development, along with the change of consumption idea and the increase of disposable income in China. It is the key to grasp the cruise tourism market characteristics and development trends for Chinese cruise tourism development. The article implements cruise tourism supply and demand quantity forecast based on the grey prediction model, analyzes the balance of the cruise industry development of China, and puts forward development ideas about government, market and industry, so as to provide reference for the future healthy development of Chinese cruise tourism.
\end{abstract}

KEYWORD: Grey Prediction Model; Chinese Cruise Tourism; Supply and Demand Equilibrium

\section{INTRODUCTION}

According to the development practice of international cruise economy, when a country or region economy's per capita GDP arrives \$60008000 , the people's life style and consumption ideas will change, and cruise economy will get rapid development (Wang Nan-nan, 2011).

In view of the above background, the Chinese national development and reform commission (NDRC) published 'instruction about promoting the development of Chinese cruise industry' in June 2008, has been clear about the guiding ideology and basic principles of the cruise industry development, put forward the overall goal, main task and targeted measures, but not yet to make detailed planning for scientific development. Cruise industry has large fixed investment, high operating costs and strong regional seasonal characteristics. Therefore, it's the key to grasp the cruise tourism market characteristics and development trends. This is especially important for emerging markets of cruise tourism like China (Zhang Yan-qing et al., 200). But Chinese domestic academic articles focus on the development status of cruise industry, cruise manufacturing, cruise toutism demand characteristics, cruise tourism competitiveness and so on, lack related research from the industrial perspective. So this article will carry out cruise tourism supply and demand forecasting from the perspective of supply and demand, carry on the balance of the cruise industry development in China, which can fill the void in the study of relevant content, and provide the reference for the healthy development of China's cruise in future.

\section{LITERATURE REVIEW}

Travel demand forecasting has extremely important role in the national tourism development policy and strategic planning, tourism resource optimization configuration, tourist enterprise strategic planning and decision-making, etc. The travel demand forecasting research began in the 1960s in Western research, it was rapid development in the $80 \mathrm{~s}$, which mainly focused on the travel demand model and the empirical analysis (Tao Wei \& Ni Ming, 2010). Chinese tourism demand forecasting research started from the end of the 20th century, as is in its infancy. The existing literature is primarily based on western research theory introduction and discussion, the empirical research is less.

At present the literature is not much about cruise travel demand forecasting, and mostly based on regional prediction researches, but the use of prediction method is different. For example, Bao Fuyuan (2011) adopts three exponential smoothing to sanya cruise tourism market scale prediction, combined with the international experience about the ratio of cruise tourists accounted for visitors. Zhai Wei-hong (2012) exploits GM $(1,1)$ grey model to predict Shanghai cruise visitors according to the statistical data of Shanghai cruise visitors in 2007- 
2010. Fu Xin-ping (2013) calculates Nanjing two kinds of cruise tourism consumption demand according to the market research of cruise tourist will, corrects the forecast data according to consumption and supply resource constraints, obtains the final prediction results. There is only one article about the Chinese cruise tourism market demand forecasting. Jia Peng (2013) uses BP neural network to design cruise travel demand forecasting model, which is trained and tested by the statistics of American cruise market and is applied to China's cruise travel demand prediction.

However, the cruise tourism supply research is few. Zheng hui (2009) finds the problem between Chinese cruise market supply and tourists demand, puts forward some targeted countermeasures about cruise tourism product development. Yang Yan-feng (2011) summarizes the present situation of world cruise tourism market, researches cruise tourism market supply characteristics in China from three aspects, including products, distribution channels, marketing.

The above literature about cruise tourism demand forecasting focus on the good and bad analysis of the prediction method, lack of effective quantitative prediction, which may be associated with the difficult statistical data acquisition. At the same time, the above literature about cruise tourism supply forecasting focus on the operating level, lack of systems analysis from the prediction level. Thus, the research about cruise tourism supply and demand is blank, which is worth to carry out the system research.

\section{CHINESE CRUISE TOURISM DEMAND AND SUPPLY FORECASTS}

\subsection{Prediction method}

Grey system theory is a new intersect discipline, which is found in 1982 by Chinese famous scholar professor Deng Ju-long. GM $(1,1)$ grey forecasting model usually applies a little foregone albino parameters, makes the grey problem desalted and bleached through analysis, modeling, control and optimization program, that is to say how to utilize the known information (white) to reveal the unknown information (gray). G shows grey, M shows model, GM $(1,1)$ shows the model wiht 1 order and a variable. Its core is accumulation of the chronological and random fluctuating to generate regular data sequence (Zhai Wei-hong, 2012).

Grey forecasting method studies on 'small sample, poor information, and uncertain 'problems. The method is simple and has high accuracy, which widely applied in Chinese domestic many fields. In particular, a lot of statistical data related to tourism development can't be obtained because of poor statistical system in China, and the data has significant uncertainty and volatility because of tourism influenced by numerous factors (economic, political, social, family, consumption etc.), which is a big grey system from the grey theory perspective. Based on this, the grey model is more suitable for the Chinaese cruise tourism market forecasts.

\subsection{Chinese cruise tourist demand forecast}

The number of Chinese cruise tourists can be found According to" China cruise development report" in 2008-2012, in which the tourists refer to the number of tourists who take abroad from mainland China, and don't include the Chinese tourists who take cruise travel from Hong Kong, Singapore, the United States, Europe and so on. Specific data as shown in table 1 .

Table 1 The number of outbound cruise tourists from China's port

\begin{tabular}{|c|c|c|c|c|c|}
\hline year & 2008 & 2009 & 2010 & 2011 & 2012 \\
\hline $\begin{array}{l}\text { The number of } \\
\text { mainland China } \\
\text { (unit: } m \text { ) }\end{array}$ & 15 & 20 & 24 & 33 & 42 \\
\hline
\end{tabular}

(ps: Due to the effect of Japanese earthquake nuclear radiation the real data is only 252000 in 2011 , the paper adopts difference method to confirm the data of 330000 in order not to affect the prediction effect)

Taking the cruise tourists for example, the paper introduces the application of grey forecasting model in detail.

(1)Data processing. establishing the original sequence is established:

$$
X^{(0)}=[15,20,24,33,42]
$$

The original sequence accumulation to generate the new sequence:

$$
X^{(1)}=[15,35,59,92,134]
$$

(2)Differential equation is established. $\operatorname{GM}(1,1)$ model's first order differential equation is:

$$
\frac{d x^{(1)}}{d t}+a x^{(1)}=u
$$

(3)Estimated parameters. The least square method is used to estimate parameters $a, u$ :

$$
\begin{gathered}
A=(a, u)^{T}=\left(B^{T} B\right)^{-1} B^{T} Y \\
B=\left(\begin{array}{cc}
-1 / 2\left[x_{1}^{(1)}+x_{2}^{(1)}\right] & 1 \\
-1 / 2\left[x_{2}^{(1)}+x_{3}^{(1)}\right] & 1 \\
\vdots & \vdots \\
-1 / 2\left[x_{n-1}^{(1)}+x_{n}^{(1)}\right] & 1
\end{array}\right) \quad Y=\left(\begin{array}{c}
x_{2}^{(0)} \\
x_{3}^{(0)} \\
\vdots \\
x_{n}^{(0)}
\end{array}\right)
\end{gathered}
$$

the original data is brought in: 


$$
B=\left(\begin{array}{cc}
-25 & 1 \\
-47 & 1 \\
-75.5 & 1 \\
-113 & 1
\end{array}\right) \quad Y=\left(\begin{array}{l}
20 \\
24 \\
33 \\
42
\end{array}\right)
$$

Through calculation: $a=-0.2572, u=13$.

(4) GM (1, 1) prediction model for: $\hat{x}^{(1)}(t+1)=\left[x^{(0)}(1)-\frac{u}{a}\right] e^{-a t}+\frac{u}{a}$ the parameter is brought in: $\bar{x}^{(1)}(t+1)=65.56 e^{0.2572 t}-50.56$

(5) Solving step by step . the accumulative sequence forecast values is obtained gradually by $t$ : $\hat{x}^{(1)}(t+1)=[15,34,59,91,133]$ the original sequenc's forecast values: $\hat{x}^{(0)}(t+1)=[15,19,25,32,42]$

(6) Results of Inspection. The average relative error of forecast data with original data is $2.75 \%$, the maximum relative error is $3.87 \%$, so the error is small. And the variance ratio: $C=\frac{S_{2}}{S_{1}}=\frac{0.1819}{9.6208}=2 \%<3.5 \% \quad$ Small error probability: $P=p\left\{\left|e(t)-e^{\prime}\right|<0.6457 S_{1}\right\}=1$

From table 2, the precision of the prediction model is the first level, and the prediction precision is good.

Table 2 GM $(1,1)$ model precision grade table

\begin{tabular}{|c|c|c|c|c|}
\hline \multirow{2}{*}{ evaluation index } & \multicolumn{4}{|c|}{ Precision grade } \\
\cline { 2 - 5 } & 1 & 2 & 3 & 4 \\
\hline$C$ & $<0.35$ & $<0.5$ & $<0.65$ & $\geq 0.65$ \\
\hline$P$ & $>0.95$ & $>0.8$ & $>0.70$ & $\leq 0.70$ \\
\hline
\end{tabular}

(7) Extrapolation prediction.

The number of Chinese cruise tourists from 2013 to 2016 can be extrapolated the prediction formula based on GM $(1,1)$ model, it is shown in table 3.

Table 3 Chinese cruise tourist quantity forecast list

\begin{tabular}{|c|c|c|c|c|c|}
\hline \multicolumn{7}{|c|}{ Predicted value (unit: $\mathrm{m}$ ) } \\
\hline Real data in & 2012 & 2013 & 2014 & 2015 & 2016 \\
\hline & 42 & 54 & 70 & 90 & 116 \\
\hline
\end{tabular}

\subsection{Chinese cruise supply forecast}

Since 2006, the international cruise companies were authorized to do business in mainland China. Costa Crociere SpA, Royal Caribbean Cruises Ltd. Genting Hong Kong Limited have established the Chinese mainland market, open up the cruise lines with starting from Chinese ports. Thus, cruise tourism supply of the key factors is from the cruise itself, namely the schedule of international cruise lines. The number of Cruise ship data can be found in
2008-2012 China cruise development report, as shown in table 4.

Table 4 The data list of Cruise ship which drive from mainland Chinese cruise port

\begin{tabular}{|c|c|c|c|c|c|}
\hline Year & 2008 & 2009 & 2010 & 2011 & 2012 \\
\hline $\begin{array}{c}\text { the departure } \\
\text { cruise ship time }\end{array}$ & 63 & 80 & 95 & 142 & 170 \\
\hline $\begin{array}{c}\text { The docked } \\
\text { cruise ship time }\end{array}$ & 49 & 76 & 128 & 120 & 115 \\
\hline
\end{tabular}

(P.S. the docked cruise ship time only shows Chinese cruise reception capacity)

According to the calculation method of the grey prediction model, the paper can obtain cruise supply quantity of 2013-2016. At the same time, the precision of the prediction model is the first level and the prediction precision is good.

Table 5 The prediction list of cruise ship which drive from mainland Chinese cruise port

\begin{tabular}{|c|c|c|c|c|c|}
\hline \multicolumn{7}{|c|}{ prediction (Unit: ship) } \\
\hline Real data in & 2012 & 2013 & 2014 & 2015 & 2016 \\
\hline & 170 & 223 & 289 & 376 & 488 \\
\hline
\end{tabular}

\section{EQUILIBRIUM ANALYSIS OF CHINESE CRUISE TOURISM SUPPLY AND DEMAND MARKET}

\subsection{Equilibrium analysis of product quantity}

At present international cruises which are operating in China are moderate scale, their pecific capacity as shown in table 6. So the paper takes 2600 as the average capacity of cruise, and concludes the capacity prediction of cruise supply market which compared with the demand predict of cruise tourism market.

Table 6 Summary table of international cruise capacity which are operating in China

\begin{tabular}{|l|l|c|}
\hline \multirow{2}{*}{ Cruise company } & hull number & $\begin{array}{l}\text { Capacity (unit: } \\
\text { m) }\end{array}$ \\
\hline Star Cruises Ltd. & Super star virgo & 1960 \\
\hline $\begin{array}{l}\text { Royal Caribbean } \\
\text { Cruises }\end{array}$ & Mariner of the Seas & 3114 \\
\cline { 2 - 3 } & Voyager of the Seas & 3840 \\
\hline $\begin{array}{l}\text { Costa Crociere } \\
\text { SpA, }\end{array}$ & Costa Atlantica & 2114 \\
\cline { 2 - 3 } & Costa Victoria & 1928 \\
\hline $\begin{array}{l}\text { Carnival } \begin{array}{l}\text { Corporation \& } \\
\text { PLC }\end{array} \\
\text { China Hna group }\end{array}$ & Sapphire Princess & 2670 \\
\hline
\end{tabular}

It can be seen that the contrast difference of Chinese cruise tourism supply and demand prediction is small from table 7 nearly three years, so to say, China's cruise market reaches equilibrium. 
However, the phenomenon of supply exceeds demand will appear in 2016.

Table 7 Cruise tourism supply and demand forecast comparison table for the next three years

\begin{tabular}{|c|c|c|c|c|}
\hline Year & 2013 & 2014 & 2015 & 2016 \\
\hline Supply (unit: m) & 55.8 & 72.3 & 94 & 122 \\
\hline Demand (unit: m) & 54 & 70 & 90 & 116 \\
\hline
\end{tabular}

The above analysis is based on supply and demand quantitative analysis, the paper also needs to carry out product structure analysis. There are the following two questions in Chinese cruise tourism development at present: (1) the operating cruise presents less type and small size characteristics from table 7. Different cruise has its unique style, involves the decorated, catering, rooms, entertainment, and many other aspects, tourists can appreciate the different cultural customs from different styles of cruise. However, the Mediterranean, Yinhai, NCL Norway, Disney cruise company don't develop the Chinese market. (2) Cruise line type is single, that is difficult to meet the diversified demand. At present Chinaese cruise line mainly concentrated in Japan and South Korea routes, Hong Kong, Macao and Taiwan routes and southeast Asia routes. Such as the Caribbean, Mediterranean routes, Chinese tourists need to transfer to the corresponding port city to carry out the course schedule.

\section{COUNTERMEASURES OF CHINESE CRUISE TOURISM DEVELOPMENT}

\subsection{The policy level}

\subsubsection{The policies about cruise industry need to formulate speedily and make cruise economy development steady and healthy .}

In order to meet the growing demand of cruise tourists, the Sate Council issued 'the national tourism and leisure programs (2013-2010)', clearly supported cruise port and yacht wharf and other leisure tourism infrastructure construction, actively developed cruise tourism and yacht tourism and other leisure products. Therefore, local governments should have issued corresponding support policy according to resource advantages and promoted local cruise tourism development.

\subsubsection{All kinds of paid vacation system need to speed up implemention in order to balance properly the number of cruise rourists.}

The cruise tourism can provide food, accommodation, transportation, traveling, shopping, entertainment service, brings tourists comprehensive travel enjoyment, especially favored by the elderly. In the current family has become the main force of cruise tourism because it is suitable for all ages.
According to"2014 China's cruise travel intention survey" which published by mango net (2014), cruise tourism will continue to maintain rapid growth in $2014,78 \%$ of survey respondents plan to choose the cruise travel way. In order to better meet the demand of cruise tourists, it's necessary to vigorously promote and implement the system of paid vacation, which adjust time and space distribution of cruise tourists.

\subsection{The market level}

\subsubsection{Attracting foreign cruise companies to enter Chinese market}

As a typical supply actuation market, the supply of new ships plays an important role in the cultivation and development of target market. Therefore, in order to meet diversified demand, each port city attracts more cruise into the market according to the demand characteristics of target market, explores all kinds of routes, lets the Chinese tourists enjoy a variety of cruise culture.

\subsubsection{Setting up the local cruise brand into the cruise market}

In order to meet the increasingly strong market, in addition to international cruise companies scramble to layout the Chinese market, Global Cruise Company in Xiamen, China Cruise Comany, Cruise Yacht Management Company of Hna Tourism set up, Chinese cruise company began to take off. Although in September 2013, Henna cruise of Hna Tourism was detained in cheju island, which led to the suspension of cruise tourism. The event of jeopardizing the interests of consumers due to the economic disputes between operators, made Henna cruise experienced a certain degree of throes, to some extent, which let Chinese know the cruise brand. Local cruise companies whose self-purchased ships or lease, should study the operation mode of abroad cruise company, develop targeted product based on the characteristics of Chinese tourists cruise consumption, set up the local cruise brand image and awareness.

\subsection{The industry level}

\subsubsection{Changing the operating strategy, effectively adjusting the low and peak seasons}

At present Chinese paid vacation system is not perfect, which make Chinese tourism season is obvious. So each cruise line should be adjusted to satisfy tourist demand of each season. In 2013, for example, Costa Atlantica cruise open winter routes, carried out the winter of no closing sales strategy, and tried to push the high-end travel around the world in the Chinese market. 


\subsubsection{Understanding Chinese cruise consumption characteristics, developing targeted products}

Chinese consumers in terms of cruise consumption show unique characteristics: such as short circuit is favoured because of less leisure time, Sightseeing of cruise ship shore is taken seriously. If cruise product design is not close to the Chinese consumers, which can also cause structural imbalance of cruise tourism. Therefore, cruise lines must pay attention to consumer demand characteristics, so as to design the targeted product and make the Chinese consumers favor.

\section{ACKNOWLEDEMENT}

The paper is supported by Shanghai University of Engineering Science's High Level Research fund projects (NO. A 25001201194), Shanghai Young Teacher Training Special Fund (NO. ZZGJD12031), MOE (Ministry of Education in China)Project of Humanities and Social Sciences (NO.13YJCZH147), Jiangsu Planned Projects for Postdoctoral Research Funds and Shanghai Young Teacher Training Special Fund (NO. ZZGJD12033).

\section{REFERENCES}

[1] Wang Nan-nan. Cruise tourism industry to development in China. Transportation Construction \& Management, 2011(9): 34-35.

[2] Zhang Yan-qing, Ma Bo, LIU Tao. Characteristics of international cruise tourism market and Chinese prospect. Tourism Forum, 2010 (4): 94-98.

[3] Tao Wei, Ni Ming. Study on the comparison of tourism demand forecast between china and western countries: basic theory and models. Tourism Tribune, 2010 (8): 1218 .

[4] Bao Fu-yuan. Prediction of the cruise tourism market size of sanya. Journal of Luoyang Normal University, 2011(7): 132-134.

[5] Zhai Wei-hong, GM (,1) gray model in the application of the cruise forecast. Journal of Tianjin Vocational Institutes, 2012 (2): 60-62.

[6] Fu Xin-ping, Chang Fei, Ying Houqiang, Zhao Jun, Zhu Yong, Nanjing cruise tourism market demand forecast analysis. Transportation Construction \&Management, 2013 (3): 17-19.

[7] Jia Peng, Liu Ruiju, Sun Ruiping, Yang Zhongzhen. A prediction model for cruise tourism demand based on BP neural network. Science Research Management, 2013 (6): 6-83.

[8] Zheng Hui. Research on the development strategy of cruise tourism products based on the demand of domestic tourist. Ocean university of China, 2009.

[9] Yang Yan-feng, Wu Xue-jiao. Research on supply characteristics of Chinese cruise tourism market. Special Zone Economy, 2011(9):165-168.

[10] http://www.xinwengao.net/release/mangocity/95333.shtml 